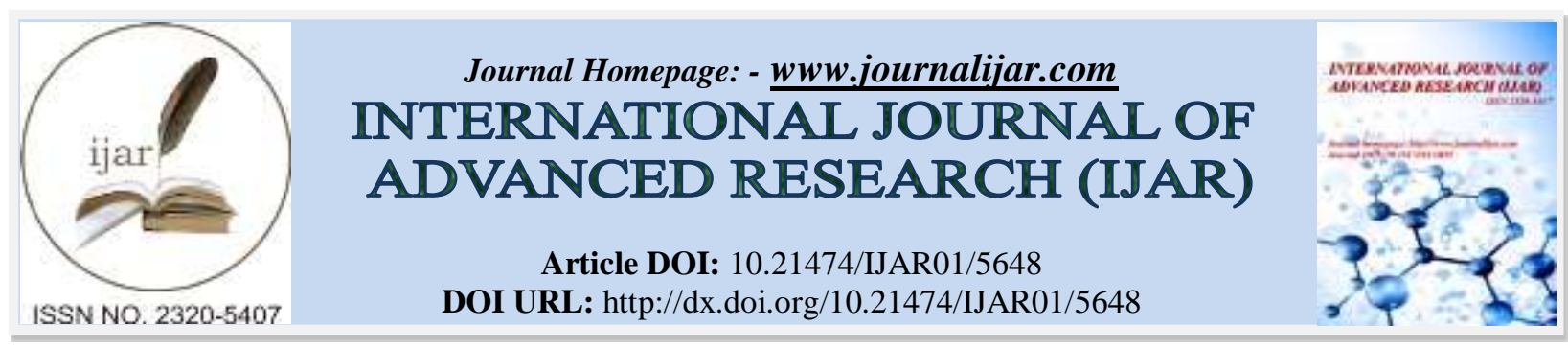

RESEARCH ARTICLE

\title{
PHARMACOGNOSTICAL AND PHARMACOLOGICAL STUDY OF GUDUCHI (TINOSPORA CORDIFOLIA).
}

\author{
*Dr. Priya Ranjan and Dr. Satyendra Kr. Singh. \\ Md(ay) amo rbsk bihar.
}

\section{Manuscript Info}

Manuscript History

Received: 17 August 2017

Final Accepted: 19 September 2017

Published: October 2017

\section{Abstract}

Copy Right, IJAR, 2017,. All rights reserved.

Pharmacognosy is the study of medicinal drugs derived from plants or other natural sources. The American Society of Pharmacognosy defines pharmacognosy as "the study of the physical, chemical, biochemical and biological properties of drugs, drug substances or potential drugs or drug substances of natural origin as well as the search for new drugs from natural sources. It is also defined as the study of crude drugs. The word 'pharmacognosy' is derived from the Greek 'pharmacon',a drug' and gignosco, 'to acquire knowledge of'. It is closely related to both botany and plant chemistry and, both originated from the earlier scientific studies on medicinal plants. With the beginning of the 20th century, the subject had developed mainly on the botanical side, being particularly concerned with the description and identification of drugs, both in the whole state and in powder and with their history, commerce, collection, preparation and storage. Such branches of pharmacognosy are still of fundamental importance, the rapid development in particularly phytochemistry and pharmacology, have enormously expanded the subject. As a result it is now possible to approach the study of medicinal plants from the botanical, phytochemical and pharmacological view points (Trease and Evams, 14th ed., 1997). Undoubtedly, the plant kingdom still holds many species of plants containing substances of medicinal value which have yet to be discovered; large numbers of plants are constantly being screened for their possible pharmacological value.

The plant selected for the present study Tinospora cordifolia, of the family Menispermaceae. Here an attempt is made to study the plant pharmacognostically in this chapter. The whole plant has taken for study. Guduchi consists of dried, matured pieces of stem of Tinospora cordifolia (Willd.) Miers. (Family- Menispermaceae), a perennial climber found throughout Tropical India, drug collected during summer preferably in the month of May, drug is used in fresh form also.

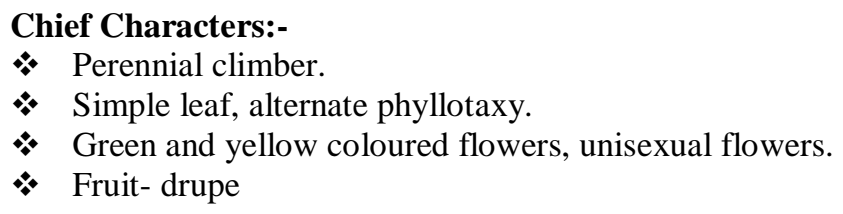

Vernacular names:-

Hindi - Amrita, Giloe, Gilincha, Gulbel, Guloh, Gulancha, Guracha. 
English- Tinospora

Gujarati- Galo, Gado, Gulo, Gulvel

Marathi - Ambervel, Gharol, Giroli, Gulavela, Wulavel, Guloe,

Marawadi - Gilve

Kachchi - Gadu

Kashmiri - Bark, Bekhgilo

Punjabi- Batinue, Gilo, Gilogularich, Zakhmihayat

Sindhi- Sutgilo

Bengali- Gudancha, Giloe, Guluncho, Nimgilo, Guruch, Golvancha,

Tamil- Amudem, Chindilkodi, Ketta-mirtu, Amridavalli,

Telugu - Gaduchi, Somida, Tippateege,tiyatij, godhuchi

Malyalam- Amrita, Katamrit, Kattamruta, paiyamritam, chidramritam

Oriya- Gulochi

Kannada- Amrutball, Madhupurne, Sundar sanbolli

Konkani- Amritvel, Garudvel

Urdu- Gilo

Arabian- Jullu, Gila

Taxonomic Position:-

* Kingdom - Plantae

* Division - Spermatophyta

* Subdivision - Angiospermae

* Class - Dicotyledonoae

* Group - Polypetalae

* Natural order - Rannals

* Family-Menispermaceae

* Genus - Tinospora

* Species - Cordifolia

\section{Distribution \& Habitat:-}

It is distributed throughout tropical Indian subcontinent and China, ascending to an altitude of $300 \mathrm{~m}$. It is a fairly common wild plant of deciduous and dry forests of most distracts growing over hedges and small trees.

\section{Species:-}

The 40 species are distributed in tropical Africa, South -East Asia, Indo Malaya region and Australia of which 3 species have been recorded from India. According to Indian medicinal plant, the following species are used medicinally.

T. bakis Miers - In Senegal

T. Cordifolia Miers - In Indo- China

T. crispa Miers - In Indo- China

T. malabarika Miers - In Indo- China

T. rumphii Boerl - Java

\section{Substitute:-}

Guduchi is a substitute for Jivak presumably Malaxis (Sivraj et.al,I.J.R.M.1986, Page 37). Substitute of Guduchi has not been mentioned in any classics. However, in practice fresh stem is more efficacious than dry and is a good substitute for Columba.

\section{Adulteration:-}

The commonest species of Tinospora with which Tinospora cordifolia is likely to be substitute or adulterated are Tinospora sinensis (lour)Merril.(syn.Tinospora malabarica(Mier) and Tinospora crispa (Linn.) are met with and often confused with each other.

\section{Part used:-}

The entire plant stem leaves and roots are used in medicine, preferably in the fresh state. 


\section{Collection:-}

The root and stem are collected in hot season when the bitter principle in most abundant and concentrated (Indian pharmacopoeia). It is not official in the British pharmacopoeia or the United state pharmacopoeia. For Sattva preparation fresh stem should be collected at the flowering time when there are no leaves in the stem to get both quantitative and qualitative starch.

\section{Side Effects:-}

No significant information on side effects is available so far. The drug is traditionally considered to be safe in the dosage mentioned.

\section{Description:-}

\section{a) Macroscopic}

Drug occurs in pieces of varying thickness ranging from $0.6-5 \mathrm{~cm}$ in diameter, young stems green with smooth surfaces and swelling at nodes, older ones show a light brown surface marked with warty protuberances due to circular lenticels, transversely smoothened surface shows a radial structure with conspicuous medullary rays traversing porous tissues, taste bitter.

\section{Botanical description:-}

It is a large, glabrous, deciduous climbing shrub.

Stem- The stem of Tinospora cordifolia is rather succulent with long filiform. Fleshy aerial roots from the branches with a thick, soft, warted

bark

Bark - The bark is creamy white to grey, deeply left spirally, the space in between being spotted with large rosette like lenticels.

Leaf- The leaves are membranous and cordate at the base. Leaves alternate, on long flexnose petioles, spreading 2-4 inches long, roundish oval, entire, acute at the apex, quite smooth and thin. The leaves have bitter taste and an indistinct odour, when the leaves seen in bulk, they look intensely green. Mature leaves show yellowish to green colour.

Flower - The flowers are small and yellow or greenish in colour. In....

auxiliary and terminal racemes or racemose panicles, the male flowers are clustered and female are usually solitary. Male flower- Sepals 6 in two rows of 3 each, the outer short \& roundish, the inner twice as long, broadly abovate, concave, smooth, petals 6 , opposite the sepals and about half length of the inner ones, 3 lobed above with the lateral lobes.

Female flower- Sepals as in the male; petals oblong spasthuatate; stamens reduced to small oblong sepals in front of the petals; carples 3, distinct, opposite the outer sepals.

Fruits- 3 or less usually less by abortion shortly, stalked, subglobose drupes. The drupes are ovoid, glossy, succulent, red and pea sized. Flowers grow during the summer and Fruits during the winter and fruits are fleshy.

Seed - The seeds are curved and single.

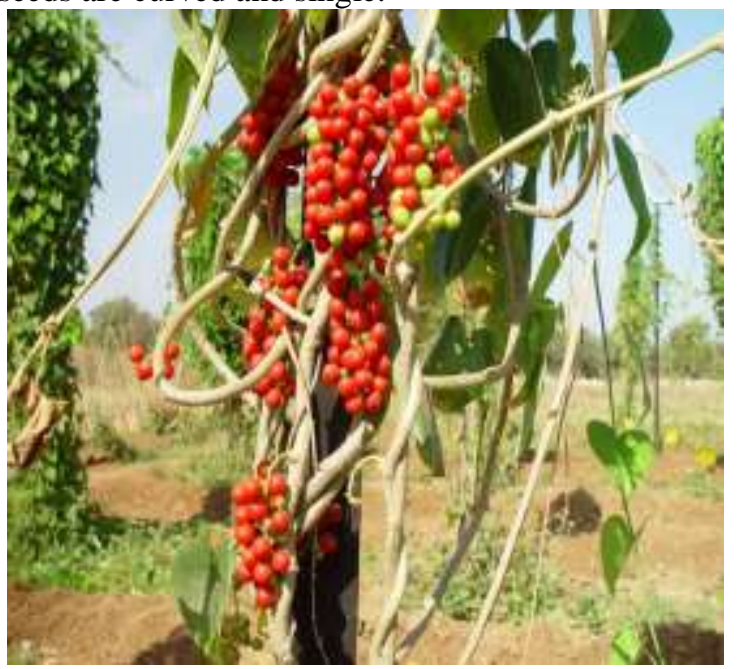

Fig. of Guduchi

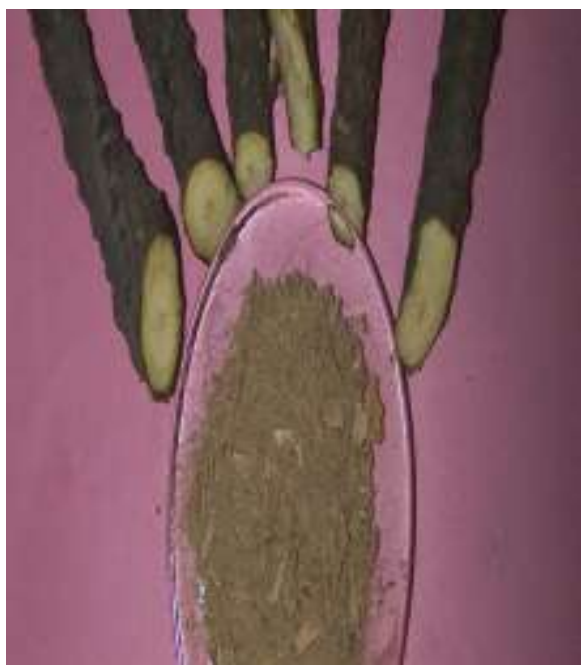

Fig. of Guduchi yavkuta 


\section{b) Microscopic:- \\ Aerial root:}

The aerial root is characterized by tetrarch primary structure; cortex is divided in to outer thick walled zone representing the velamen and inner parenchymatous zone containing secretary canals and starch grains are present throughout the parenchyma of the aerial root.

\section{Stem:}

Transverse section of stem shows outer-most layer of cork, differentiating into outer zone of thick-walled brownish and compressed cells, inner zone of thin walled colourless, tangentially arranged 3-4 rows of cells, cork broken at some places due to opening of lenticels, followed by 5 or more rows of secondary cortex of which the cells of outer rows smaller than the inner one, just within the opening of lenticels, groups of sclereids consisting of 2-10 cells found in secondary cortex region, outer zone of cortex consists of 3--5 rows of irregularly arranged, tangentially elongated chlorenchymatous cells, cortical cells situated towards inner side, polygonal in shape and filled with plenty of starch grains, simple, ovoid, or irregularly ovoid-elliptical, occasionally compound of 2-4 components, several secretory cells, found scattered in the cortex, pericyclic fibres lignified with wide lumen and pointed ends, associated with a large number of crystal.

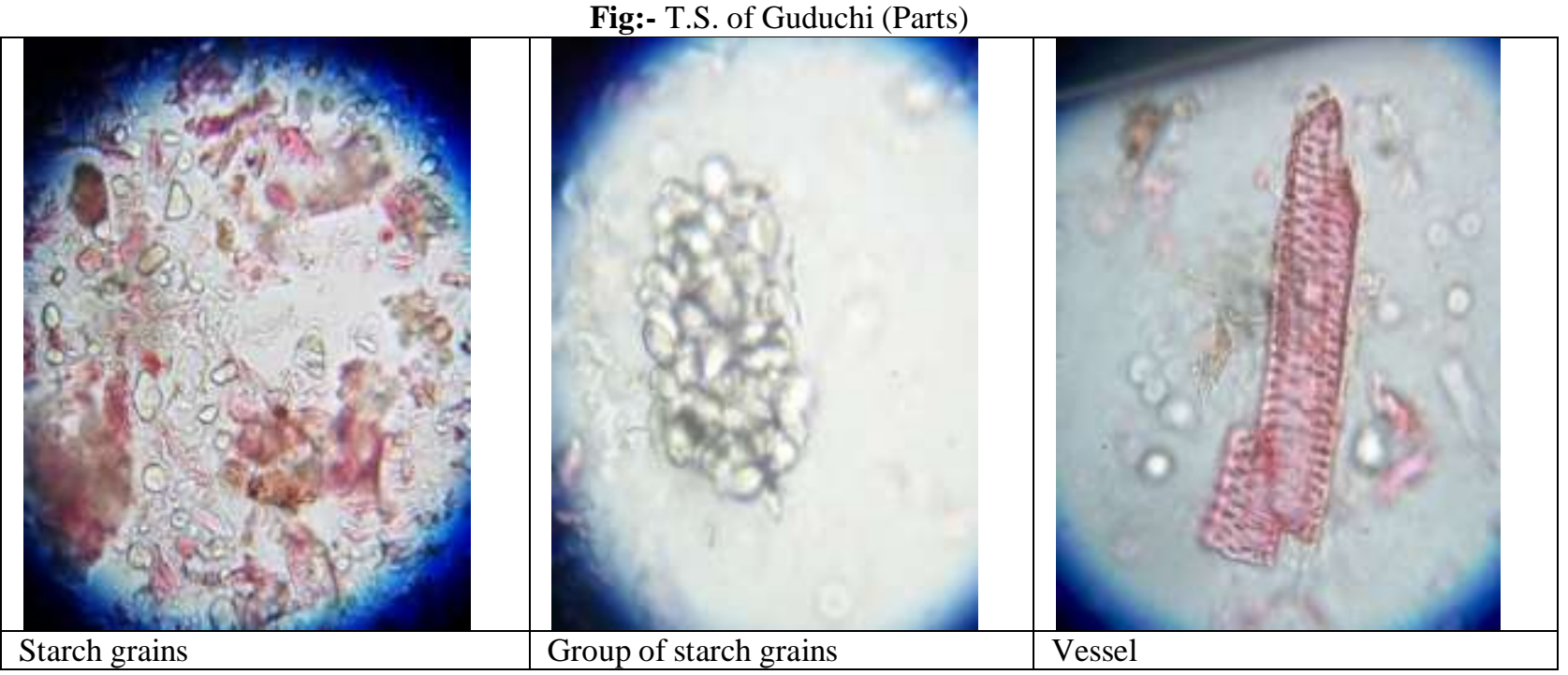

fibres containing a single prism in each chamber, vascular zone composed of10-12 or more wedge-shaped strips of xylem, externally surrounded by semi-circular strips of phloem, alternating, with wide medullary rays, phloem consists of sieve tube, companion cells and phloem parenchyma of polygonal or tangentially elongated cells, some of them contain crystals of calcium oxalate, cambium composed of one to two layers of tangentially elongated cells in each vascular bundle, xylem consists of vessels, tracheids, parenchyma and fibres, in primary xylem, vessels comparatively narrow devoid of tyloses, secondary xylem elements thick-walled, lignified, vessels cylindrical in shape bearing bordered pits on their walls some large vessels possess several tyloses and often contain transverse septa, meduallry rays 15-20 or more cells wide containing rounded, hemispherical, oblong, ovoid, with faintly marked concentric striations and central hilum appearing like a point, starch grains of 5.5-11.20 $\mu$ in diameter and 6$11.28 \mu$ in length, pith composed of large, thin-walled cells mostly containing starch grains. Powder microscopy of the drug showed hemispherical to ovoid starch grains and pitted vessel.

Chemical Composition

\begin{tabular}{|l|l|l|}
\hline Type of Chemical & Active principle & Part in which present \\
\hline Alkaloids & $\begin{array}{l}\text { Berberine (I), Palmatine (II), Tembetarine(III, 0.012\%) } \\
\text { Magnoflorine (IV, 0.075\%), Stem } \\
\text { Choline (V), Tinosporin, Isocolumbin, } \\
\text { Palmatine,Tetrahydropalmatine (VI), } \\
\text { Magnoflorine }\end{array}$ & Root \\
\hline Glycosides & 18-norclerodane glucoside (VII),Furanoid & Stem \\
\hline
\end{tabular}




\begin{tabular}{|c|c|c|}
\hline & $\begin{array}{l}\text { diterpene glucoside (VIII and } \\
\text { IX),Tinocordiside (X),Tinocordifolioside } \\
\text { (XI)., Cordioside, Cordifolioside A, } \\
\text { Cordifolioside B,Syringin (XII), Syringinapiosylglycoside, } \\
\text { Palmatosides C, Palmatosides F, } \\
\text { Cordifoliside A (XIII), Cordiofoliside } \\
\text { B,Cordifoliside C,Cordifoliside D, } \\
\text { Cordifoliside E }\end{array}$ & \\
\hline Diterpenoid & $\begin{array}{l}\text { Furanolactone XIV, } \\
\text { Lactones Clerodane derivatives XV, XVI and XVII } \\
\text { [(5R,10R)-4R-8R-dihydroxy-2S-3R:15,16-diepoxy-cleroda- } \\
\text { 13 (16), 14-dieno-17, } \\
\text { 12S:18,1S-dilactone] and } \\
\text { Tinosporon,Tinosporides XVIII and } \\
\text { XIX,Jateorine (XX), Columbin (XXI) }\end{array}$ & $\begin{array}{l}\text { Whole } \\
\text { plant }\end{array}$ \\
\hline Steroids & $\begin{array}{l}\text { b -sitosterol (XXII), d-sitostero, 20bhydroxy } \\
\text { ecdysone (XXIII). } \\
\text { Ecdysterone (XXIV), Makisterone A } \\
\text { (XXV),Giloinsterol. }\end{array}$ & $\begin{array}{l}\text { Aerial part } \\
\text { Stem }\end{array}$ \\
\hline $\begin{array}{l}\text { Sesquiterpenoid } \\
\text { Aliphatic } \\
\text { Compound } \\
\text { Miscellaneous } \\
\text { compounds }\end{array}$ & $\begin{array}{l}\text { Tinocordifolin, } \\
\text { Octacosanol (XXVI), Heptacosanol (XXVII), } \\
\text { Nonacosan-15-one (XXVIII), } \\
\text { 3,(a,4-di hydroxy-3-methoxy-benzyl)-4-(4-hydroxy-3- } \\
\text { methoxy-benzyl)- } \\
\text { tetrahydrofuran. } \\
\text { Jatrorrhizine (XXIX). } \\
\text { Tinosporidine, Cordifol, Whole plant Cordifelone,N-trans- } \\
\text { feruloyl tyramine as diacetate,Giloin,Giloinin, Tinosporic acid }\end{array}$ & $\begin{array}{l}\text { Stem } \\
\text { Whole } \\
\text { Plant } \\
\text { Whole } \\
\text { Plant } \\
\text { Root } \\
\text { Whole } \\
\text { plant }\end{array}$ \\
\hline
\end{tabular}

\section{Rasapanchaka [Pharmacological action ]}

Rasa (taste) : Tikta, Kasaya

Guna (quality) : Laghu,Guru

Virya (action) : Ushna

Vipaka (post digestive effect): Madhur

Doshghnta : Tridoshaghnta

Properties and Action: -Deepaniya, Trishnanigrahan, Rasayana, Balya, Ayushprada, Medhya ,Jwarahara, Dahaprashaman, Kushtaghna, Amavataghna, Raktashodhana, Sukrashodhana, Vajikarana ,Vayasthapana,

Tridoshahara

Therapeutic indication:

In our classics of Ayurveda, Guduchi is indicated to treat various disorders like Jwara, Jirnajwara, Visamajwara, Kustha, Visharpa, Kandu, Daha, Vatarakta, Krimiroga, Pandu, Kamla, Halimaka, Pravahika, Grahni, Daurbalya, Hriddaurbalya, Dhatukshaya, Kshya, Prameha, Mutrakrichha, Phiranga

\section{Doses:}

Powder - 1-3 masa (3-6g)

Decoction - 4-8 tola (50-100ml)

Sattva - 5-15 ratti (1-2g)

Formulation:

Churna - Rasayan churna, Sudarsana churna

Kwatha - Guduchyadi kwatha, Manjisthadi kwatha, Punarnavastaka kwatha

Arista - Amritarista

Ghrita - Guduchi Ghrita, Amritadi Ghrita, Panchatikta Ghrita

Taila - Guduchyadi taila

Vati - Samsamni vati, Chandraprabha vati

Lauha - Guduchyadi lauha

Rasa-ausadhi - Gandhak rasayan, Chandrakala rasa

Pharmacological activity: 
Many research works have been carried out on Tinospora cordifolia with different activities i.e. adaptogenic, anti neoplastic, anti diabetic, anti bacterial, miscellaneous. But here some research works have been mentioned which are related to this study.

Immunomodulating activity:-

- Syringin, Cordiol, Cordioside and cordifoliside were found to possess immunopotentiating activity.

- Tinospora cordifolia was found to have immunomodulating activity.

Anti-inflammatory activity:-

- The aqueous extract of Tinospora cordifolia showed significant anti inflammatory activity in rats against acute and chronic type of inflammation induced by carrageenin and the activity resembles that of NSAIDS.

- Singh et al. have shown that the aqueous suspension of the alcoholic extract of the stem of T. cordifolia provided protection to liver damage induced by administration of carbon tetrachloride in mice, rats, and rabbits.

- The decoction of Tinospora cordifolia showed anti-inflammatory activity on carrageenin induced hind paw edema in rats.

\section{Hepato-protective activity:-}

A study of hepato-protective activity of T. cordifolia on Kupffer cell function using carbon clearance test as a parameter showed significant improvement in kupffer cell function and a trend towards normalization. Tinospora cordifolia appears to improve surgical outcome, in patient with malignant obstructive jaundice by strengthening the host defenses. Thus the Ayurvedic use of the plant in liver ailments is justified although the Active principle is yet to be isolated and identified.

\section{Anti- stress activity:-}

- The ethanolic extract of Tinospora cordifolia exhibited significant anti stress activity at $100 \mathrm{ml} / \mathrm{kg}$ compared with diazepam at $2.5 \mathrm{mg} / \mathrm{kg}$. The ethanolic extract of Tinospora cordifolia at a dose $100 \mathrm{mg} / \mathrm{kg}$ was shown to induce a marked protective action against $8 \mathrm{hr}$ restraint stress induced ulcerization.

- Sharma and Khosla have reported that the alcoholic extract of Tinospora cordifolia roots possessed normalizing activity against stress induced changes in nor epinephrine, dopamine, 5- HT and 5 hydroxyindoleaceticacid levels of experimental rats.

Anti-histaminic activity:-

- Tinospora cordifolia stem extract significantly decreased bronchospasm induced by $5 \%$ histamine aerosol in Guinea pig and permeability in mice. It also reduced the no. of disrupted mast cell in rats.

\section{Preliminary Screening of Phytochemicals:-}

The preliminary phytochemical studies were performed for testing the different chemical groups present the drug. $10 \%$ (w/v) solution of extract was taken unless otherwise mentioned in the respective individual test. General screening of various extracts of the plant material was carried out for qualitative determination of the groups of organic compounds present in them (Trease and Evan, 1983).

\section{Alkaloids}

a) Dragendorff's test: Dissolve a few mg of alcoholic or aqueous extract of the drug in $5 \mathrm{ml}$ of distilled water, add $2 \mathrm{M}$ hydrochloric acid until an acid reaction occurs, then add $1 \mathrm{ml}$ of Dragendorff's reagent, an orange or orange-red precipitate is produced immediately. Hager's test: To $1 \mathrm{ml}$ of alcoholic extract of the drug taken in a test tube, add a few drops of Hager's reagent. Formation of yellow precipitate confirms the presence of alkaloids.

b) Wagner's test: Acidify $1 \mathrm{ml}$ of alcoholic extract of the drug with $1.5 \% \mathrm{v} / \mathrm{v}$ of hydrochloric acid and add a few drops of Wagner's reagent. A yellow or brown precipitate is formed.

c) Mayer's test: Add a few drops of Mayer's reagent to $1 \mathrm{ml}$ of acidic aqueous extract of the drug. White or pale yellow precipitate is formed.

\section{Carbohydrates}

a) Anthrone test: To $2 \mathrm{ml}$ of anthrone test solution, add $0.5 \mathrm{ml}$ of aqueous extract of the drug. A green or blue colour indicates the presence of carbohydrates.

b) Benedict's test: To $0.5 \mathrm{ml}$ of aqueous extract of the drug add $5 \mathrm{ml}$ of Benedict's solution and boil for 5 mins. Formation of a brick red coloured precipitate is due to the presence of carbohydrates. 
c) Fehling's test: To $2 \mathrm{ml}$ of aqueous extract of the drug add $1 \mathrm{ml}$ of a mixture of equal parts of Fehling's solution ' $A$ ' and Fehling's solution 'B' and boil the contents of the test tube for few minutes. A red or brick red precipitate is formed.

d) Molisch's test: In a test tube containing $2 \mathrm{ml}$ of aqueous extract of the drug add 2 drops of a freshly prepared $20 \%$ alcoholic solution of $\beta$ - naphthol and mix, pour $2 \mathrm{ml}$ conc. sulphuric acid so as to from a layer below the mixture. Carbohydrates, if present, produce a red-violet ring, which disappears on the addition of an excess of alkali solution.

3. Flavonoids- Shinoda's test: In a test tube containing $0.5 \mathrm{ml}$ of alcoholic extract of the drug, add 5-10 drops of dil. hydrochloric acid followed by a small piece of magnesium. In the presence of flavonoids a pink, reddish pink or brown colour is produced.

\section{Triterpenoids}

Liebermann-Burchard's test: Add $2 \mathrm{ml}$ of acetic anhydride solution to $1 \mathrm{ml}$ of petroleum ether extract of the drug in chloroform followed by $1 \mathrm{ml}$ of conc. sulphuric acid. A violet colour coloured ring is formed indicating the presence of triterpenoids.

5. Proteins -Biuret's test: To $1 \mathrm{ml}$ of hot aq extract of the drug add 5-8 drops of 10\% w/v sodium hydroxide solution followed by 1 or 2 drops of 3\% w/v copper sulphate solution. A red or violet colour is obtained. Millon's test: Dissolve a small quantity of aqueous extract of the drug in $1 \mathrm{ml}$ of distilled water and add 5-6 drops of Millon's reagent. A white precipitate is formed which turns red on heating.

6. Resins- Dissolve the extract in acetone and pour the solution into distilled water. Turbidity indicates the presence of resins.

7. Saponins- In a test tube containing about $5 \mathrm{ml}$ of an aqueous extract of the drug add a drop of sodium bicarbonate solution, shake the mixture vigorously and leave for 3 mints. Honeycomb like forth is formed.

\section{Steroids}

D. Liebermann-Burchard's test: Add $2 \mathrm{ml}$ of acetic anhydride solution to $1 \mathrm{ml}$ of petroleum ether extract of the drug in chloroform followed by $1 \mathrm{ml}$ of conc. sulphuric acid. A greenish colour is developed which turns to blue.

$>$ Salkowski Reaction: Add $1 \mathrm{ml}$ of conc. sulphuric acid to $2 \mathrm{ml}$ of chloroform extract of the drug carefully, from the side of the test tube. A red colour is produced in the chloroform layer.

9. Tannins- To $1-2 \mathrm{ml}$ of plant extract, add a few drops of $5 \% \mathrm{FeCl} 3$ solution was added. A green colour indicates the presence of gallotannins, while brown colour tannins.

10. Starch- Dissolve $0.015 \mathrm{~g}$ of Iodine and $0.075 \mathrm{~g}$ of Potassium Iodide in $5 \mathrm{ml}$ of distilled water and add $2-3 \mathrm{ml}$ of an aqueous extract of drug. A blue colour is produced.

\section{Glycosides-}

Detection of glycoside on paper spray solution No. 1 ( $0.5 \%$ aqueous sol. of Sodium metaperiodate) \& wait for 10 minutes after then spray solution No. 2 [0.5\% Benzidine (w/v) in solution of Ethanol - acetic Acid (4:1)], white spot with blue back ground shows presence of glycoside.

\section{Identity, Purity And Strength:-}

\section{Loss on drying at $105^{\circ} \mathrm{C} /$ Moisture content.}

Place about $10 \mathrm{gm}$ of drug sample after accurately weighing it in a tared evaporating dish. After placing the above said amount of sample in a tared evaporating dish dry at $105^{\circ} \mathrm{C}$ for 5 hours and weigh. After drying tared evaporating dish cool in desiccator for 30 minutes and then weight.

Difference in weight after heating x 100

The $\%$ of Loss on drying $=$

Weight of sample taken

\section{Determination of Ash:-}

\section{Determination of Total Ash:-}

About $2.0 \mathrm{~g}$ of powdered drug was incinerated in a tared silica dish at a temperature not exceeding $450^{\circ} \mathrm{C}$ until free carbon was left, cooled and final weight was taken. The percentage of ash calculated with reference to the air-dried drug (PASF, 1987). 


\section{Determination of Acid Insoluble Ash:-}

The ash obtained as above method was boiled for 5 minutes with $25 \mathrm{ml}$ of dilute hydrochloric acid and collected the insoluble matter on an ash-less filter paper, washed with hot water and ignited to constant weight. The percentage of acid-insoluble ash with reference to the air dried drug was calculated (PASF, 1987).

\section{Determination of Sulphated Ash:-}

Heat a silica crucible to redness for 10 minutes; allow cooling in a desiccator and weighing. Put about $2.0 \mathrm{~g}$ of powdered drug into the crucible; ignite gently at first, until the sample is thoroughly charred. Cool, moisten the residue with $1 \mathrm{ml}$ of sulphuric acid, heat gently until white fumes are no longer evolved and ignite at $800^{\circ} \pm 25^{\circ}$ until all black particles have disappeared. Allow the crucible cool; add few drops of sulphuric acid and heat. Ignite as before, allow to cool and final weight was taken after two successive operation repetitions.

\section{Determination of Extractable Matter in water and alcohol:-}

About 4.0g of coarsely powdered air dried material, was accurately weighed in a glass stoppered conical flask and macerated with $100 \mathrm{ml}$ of the solvent specified for the plant material concerned for 6 hours, shaking frequently, then allowed to stand for 18 hours. Filtered rapidly, taking care not to lose any solvent. The extracted matter was dried at $105^{\circ} \mathrm{C}$ for 6 hours, cooled in a desiccator for 30 minutes and then weighed. The percentage extractable matter was calculated.

\section{Identity, Purity And Strength}

\begin{tabular}{|l|l|}
\hline Foreign matter & Not more than $2 \%$ \\
\hline Moisture content & $3.5 \%$ \\
\hline Total ash & $8.6 \%$ \\
\hline Acid - insoluble ash & $2.35 \%$ \\
\hline Sulphated ash w/w & $9.3 \%$ \\
\hline Alcohol - soluble extractive & $6.6 \%$ \\
\hline Water - soluble extractive & $16.5 \%$ \\
\hline
\end{tabular}

\section{Chemical Tests}

Steroids - $\quad+$ ve

Terpenoids $\quad-\quad+$ te

Alkaloids $\quad-\quad+$ +ve

Tannin - +ve

Carbohydrade - +ve

Fluorescence Study:-

[Chase \& Pratt, 1949.,Kokaski, et al.,1958) with some modification]

\begin{tabular}{|l|l|l|l|}
\hline S.no & Treatment & Under ordinary light & Under UV-Long (366nm) \\
\hline 1. & Drug as such & Brown & Light grey \\
\hline 2. & Drug+Nitrocellulose & Dark brown & Grey \\
\hline 3. & Drug + Picric acid & Dark brown & Brown \\
\hline 4. & Drug + HCl conc. & Brown & Black \\
\hline $\mathbf{5 .}$ & Drug + H2SO4 conc. & Black & Light grey \\
\hline 6. & Drug + HNO3 (50\%) & Dark brown & Grey \\
\hline $\mathbf{7 .}$ & Drug + 1 N Na OH in Me OH & Light brown & Violet \\
\hline $\mathbf{8 .}$ & Drug + 1 N Na OH in Water & Blackishbrown & Grey \\
\hline $\mathbf{9 .}$ & Drug + NH4OH & Blackish brown & Brown \\
\hline $\mathbf{1 0}$ & Drug + FeCl3 & Greenishbrown & Black \\
\hline $\mathbf{1 1}$ & Drug + Acetic acid Glacial & Reddish brown & Grey \\
\hline $\mathbf{1 2}$. & Drug + Sudan-III & Light brown & Grey \\
\hline
\end{tabular}

Thin Layer Chromatography:-

The principle underlying the separation of the compounds is their adsorption at the solid-liquid interface. For successful separation the compounds of the mixture should show different degrees of affinity for the solid support (or adsorbent) and the interaction between adsorbent and the component must be reversible. As the adsorbent is 
washed with the fresh solvent, the various components move down the column and arrange themselves in the order of affinity to the adsorbent. Those with the least affinity move down the column at a faster rate than those with greater affinity.

\section{Materials used:}

All the TLC plates used for the analysis were prepared with silica gel containing binder. Most frequently used binder in silica gel is calcium sulphate (Silica gel $60 \mathrm{~F}_{254}$, Merck). Precoated aluminium sheets were also used which is coated with silica gel $60 \mathrm{~F}_{254}$ (Merck).

\section{Preparation of TLC plates :}

Required quantity of silica gel was mixed in a glass mortar to as smooth consistency with the requisite amount of water and the slurry quickly transferred to the spreader. The mixture has been spreaded over the plates in thickness of $0.2 \mathrm{~mm}$ and was allowed to set into a thin layer. The plates were transferred carefully to a suitable holder and after 30 minutes, dried and heated at $100-120^{\circ} \mathrm{C}$ for at least one hour. The plates were kept in a desiccates after cooling, until required for further use. The pre coated plates were also activated by heating them for 30 minutes at $100^{\circ} \mathrm{C}$.

\section{Application of sample:}

A known quantity of sample was dissolved in a known volume of solvent and the sample applied on pre coated TLC plates.

Selection of Solvent Systems- The choices of the solvents depend upon the nature of the substances to be separated and also in the material on which the separation is to be achieved. The solvents system was selected on the basis of trial and error method and by elutropic series. It has been found that combination of two solvents gave better separation than with a single solvent.

\section{Chromatographic development (separation):}

Development of the chromatogram is effected after the solvent of the applied sample is completely evaporated. Rectangular glass chambers or twin trough chambers are commonly used for TLC development.

Detection of spots:

Detection of Rf. Values of spot done by using Iodine exposure and Vanillin Sulphuric Acid Reagent 


\section{TLC alcoholic extract of Guduchi}

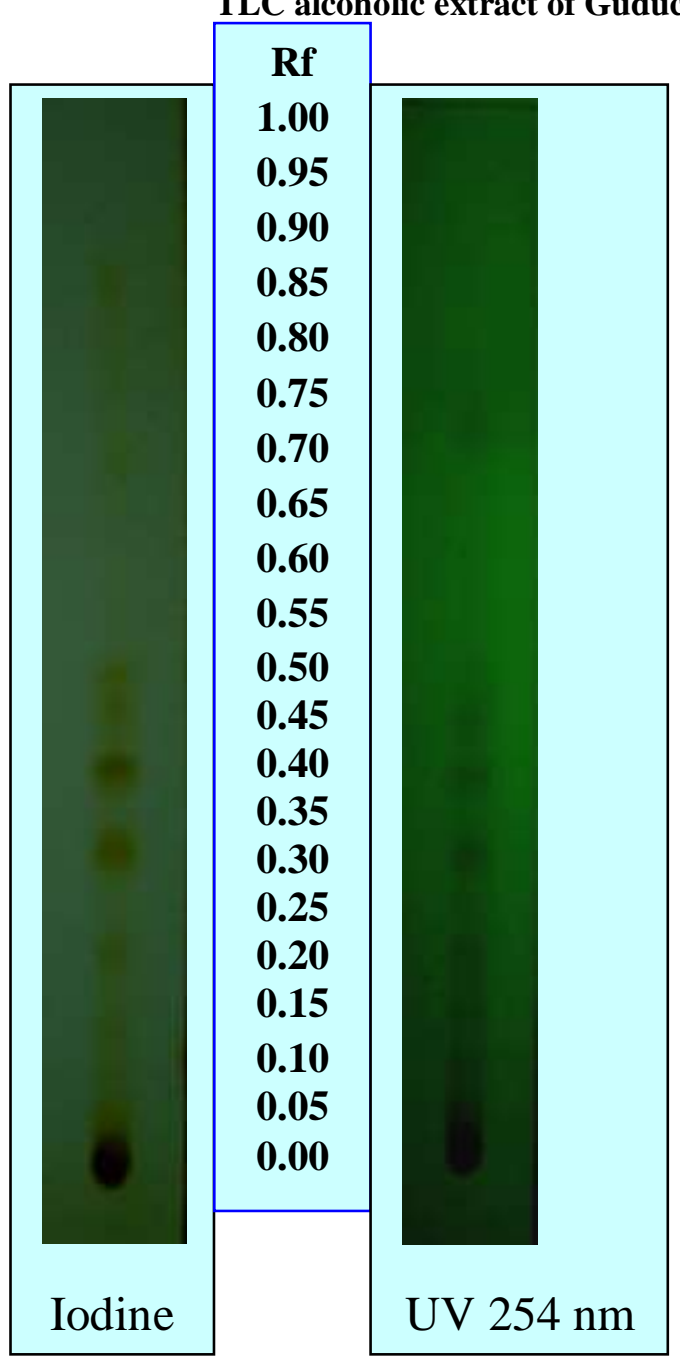

\begin{tabular}{|l|ll|}
\hline Stationary phase & TLC Aluminium sheet silica gel 60 F 254 plate \\
\hline Mobile phase & Toluene - Ethyl Acetate - Methanol - Formic Acid $\quad(7: 3: 1: 0.3)$ \\
\hline $\begin{array}{l}\text { Rf value of spots visualized in } \\
\text { Iodine }\end{array}$ & $0.15,0.20,0.30,0.35,0.45,0.70 \& 0.85$ \\
\hline $\begin{array}{l}\text { Rf value of spots visualized in UV } \\
254 \mathrm{~nm}\end{array}$ & $0.20,0.30,0.35,0.42 \& 0.68$ \\
\hline
\end{tabular}

\section{Results:-}

TLC results indicate alcoholic extract of Guduchi (Kanda) Rf value of spots visualized in Iodine at $\mathrm{Rf} 0.15,0.20$, $0.30,0.35,0.45,0.70 \& 0.83$ (7 spots), Rf value of spots visualized in UV $254 \mathrm{~nm}$ at $\mathrm{Rf} 0.20,0.30$,

$0.35,0.42 \& 0.68$ ( 5 spots).

\section{References:-}

1. PSAF. Pharmacopoeial Standards for Ayurvedic Formulations. Central Council for Research in Ayurveda and Siddhha. Ministry of Health and Family Welfare, Govt of India, New Delhi. (1987).

2. Trease, G. E. and Evan, W. C. Pharmacognosy. $12^{\text {th }}$ edition, English Language Book Society, Balliere, Tindall. (1983).

3. WHO. Quality Control Methods for Medicinal Plant Materials. World Health Organisation, Geneva. (1998).

4. Chase, C.R. and Pratt, F.J. Fluorescence of powered vegetable drugs with particular reference to development of a system of identification J. Am. Pharm. Assoc. (38) 324-331(1949) 
5. Madanpala Nighantu with Hindi Commentary by Ramprasad vaidyopdhaya Kamaraj Shrikrishnadas Prakasana, ShriVenkateswar press, Bombay, India, 1990.

6. Madhava Dravyaguna (Bhavaswabhavadah)Ed. By P.V.Sharma, Chaukhambha Sansthan, Varanasi, India 1973

7. Narahari, Rajanighantu with Hindi commentary Tripathi I.D.,Krishnadas Academy, Varanasi, 1982 .

8. Sarangadhara Samhita, Subodhini Hindi Commentary by Prayagdatta Sharma,

9. Satuavati G.V. et al. Medicinal plants of India (Vol.1-1976 and II.1987) Indian Council for Maicinal Research. New Delhi. 